\title{
A Book full of Sound and Fury
}

\section{Kenneth Stow}

Storicamente, 3 (2007).

ISSN: 1825-411X. Art. no. 22. DOI: 10.12977/stor547

I have been very disturbed in reading so many reactions on lists like $\mathrm{ml}$ sisem to Ariel Toaff's book. Scholars, who, in fact, lack the tools for discerning the real structure of the book, who cannot read a word of the Hebrew texts that are so central to the case, who cannot know when those texts were written - for the most part centuries after the affair at Trent are asking how is it that a historian of note could write a book without a true scholarly basis, so that if the book has been withdrawn, it must be because of pressures that do not fit properly within our concept of academic free speech. So let me begin by stating two things. First, there are those who have never been happy with Toaff's work, especially its fidelity to sources. Second, that anybody who, today, gets involved in defending Toaff on the grounds of free speech will, tomorrow, find him or herself with "egg on his face", that is, embarrassed when, after reading the book, but especially its notes, it becomes clear how badly it is constructed.

Judged by scholarly standards of historical research, this book is a failure. If Toaff withdrew it, this was no doubt because he realized that his attempt to fool the reader had fallen flat on its face; or maybe it was the people at II Mulino, who realized their mistake, but let Toaff save face by announcing the withdrawal himself. I repeat, from a strictly scholarly point of view-with respect to method alone, and with no reference whatsoever to the conclusion - this is an atrocious work. Its reads like a bad first year student's term paper, nothing more, and perhaps less; I, for one, am not convinced that Toaff was unaware beforehand of his works flaws and its difficult 
approach to the "facts".

I am concerned about the affects of the work, not so much on anti-Semites or the radical Arab world, which, at this very moment, is showing televisions scripts touting the blood libel. Nothing will de-convince these bigots. What worries me is exactly what has happened, that those of us who care about academic freedom, will take up the cause of this book, only first to embarrass themselves, but then to give fuel to the forces aligned against academic freedom, and they are many, convincing them their suspicions have always been correct. This book is destructive of everything the historical profession stands for, which is objective research, or at least research that we strive to make objective. Objective is a criterion that does not apply here; and I stress, objective vis-à-vis the evaluation of evidence. To historians, Toaff owes an explanation. I will now elaborate on these claims, first in broad terms, then through an addenda of maladroit particulars.

To begin with, the thesis of Pasque di sangue is unambiguous: Jews crucified Christian children and used their blood ritually. The author's disclaimers, like that which appears in a recent article in the "Chronicle of Higher Education», are unpersuasive. The argumentation of the thesis is also elusive. To wit, discussions of the negativity Jews expressed about Christianity during the festivals of Purim and Passover and the prominence of blood-imagery in especially Passover rituals (chapters 10 and 11) are followed by the opening words to chapter 12 , which say:

L'uso del sangue d'infante cristiano nella celebrazione della Pasqua ebraica era apparentemente oggetto di una normativa minuziosa, per lo meno da quanto risulta dalle deposizioni di tutti gli imputati al processo di Trento [The use of the blood of Christian children in the celebration of Passover was apparently framed by precise rules, or at least this is what the depositions in the Trent trial indicate.]

Mere juxtaposition — of itself, and by itself: abstract imagery morphing into "acting out" — is at once the totality of the "proof" brought to suggest Jews 
committed ritual murder, as well as its vague disclaimer, found in the words «or at least». But, as it proceeds, the book neglects disclaimer to recast as unimpeachable the confessions made by the Jews tried for the (supposed) murder of the child Simone at Trent in 1475. The reader is equally to accept as true the tale of a Christian boy allegedly murdered by Jews in 415, although the sole teller is the Church historian, Socrates, no more reliable than his counterpart who wrote that during the Persian conquest of Jerusalem in 611 C.E., the Jews murdered 50,000 Christians. An article based on such evidence would be rejected by the journal I have been editing for twenty years, «Jewish History» as methodological flawed.

To disparage this book is not, as some have suggested, to challenge academic freedom. It is to decry bad historiographical method. The question is not whether historians have the right to assess the veracity of ritual murder charges, but whether their arguments must adhere to generally agreed rules of historical reasoning. Here, the rules were plainly ignored. Toaff, credulously, one hopes, puts his trust in the literal words of Christian chroniclers, court notaries, and tendentious modern polemicists. In particularly in its final chapters, his book glides from images of martyrdom found in Hebrew Crusade chronicles, alongside maledictions of Christianity in the mouths of exhausted and many times massacred Ashkenazic Jews, to the supposed reality of ritual murder, framed as vendetta. And he does so on the sole basis of the appearance of these images and maledictions in the depictions of Simone's death elicited by torture from the accused. More likely, as I see it, the accused were recasting older imagery as real event in order to satisfy their tormentors. Jews, no doubt, had also imbibed what Christians were saying, which they may well have regurgitated when "put to the question". Under duress, their mentality may have come to gibe with that of their prosecutors.

Toaff might at least have raised these possibilities, but he never does. For this would have meant abandoning a narrative mode which, as it is now, is but a skein of speculations offered as self-evident truth by an omniscient 
author. It is this totally self-assured, and uncritical narrative that makes this book so treacherous. The tale is told as though its author were vouchsafed with the "truth". The passage from the verifiable to the hypothetical is completely unmarked. And it is for this reason that the book wreaks such havoc, of itself, for what it says, on the author, and no less on its publisher II Mulino.

What the book never confronts is the other side of the coin, to query whether charges of ritual murder, blood libels, or host desecration were intrinsic to Christian discourse, regardless of Jewish actions. A short time ago, Bernard Joassart, head of the Bollandists, the Jesuit students and collectors of Saints Lives in Antwerp, wrote me, saying:

Cette affaire du meurtre rituel a traîné longuement dans la conscience catholique - et je ne suis pas sûr que tous ont révisé leur jugement. 
Joassart was following in the path of Bollandist predecessors like Hippolyte Delehaye (Joassart is also Delehaye's biographer), Francois Halkin, and Francois Van Ortroy, who nearly a century ago described ritual murder and blood libels as inanité. Embroiling himself with Jesuit authorities in Rome, who, at that time, were touting ritual murder libels, Van Ortroy wrote a scathing review denouncing G. Divina's 1902 Storia del Beato Simone (the title says all), which calls the charge of killing Simon of Trent in 1475 true. Yet it is precisely Divina, together with Benedetto Bonelli's, Dissertazione apologetica sul martirio del beato Simone da Trento of 1747, whom Toaff repeatedly cites, far more, in fact, than the trial records themselves (condemned in their own day by the Dominican legate Bishop Battista de' Giudici and seconded, if indirectly, by the then Franciscan Pope Sixtus IV) to prove that ritual murders actually took place. Toaff thus finds himself squarely on the side of Van Ortroy's arch-conservative opponents (as he could have known from my recent Jewish Dogs: An Image and Its Interpreters [Stanford 2006], which he cites in his notes).

Alas, ritual murder, blood libel, and host libel charges have been integral to ecclesiology from the earliest. The story of the Jewish boy of Bourges, whose father threw him into a furnace rather than letting him take communion was being told already in the mid-sixth century. The boy stands for the Eucharist, just as in like fashion, Werner of Oberwessel, said to have been martyred in 1287, was identified with the corpus verum (the Eucharist), the corpus mysticum (the church), as well as with Christ's real person ( Acta Sanctorum, April 2:699-700). The purpose of the charges was to demonstrate the Eucharist's unassailability, even when it was being pursued by those whom first John Chrysostom (fourth century) and eventually Pius IX (nineteenth century) called «Jewish Dogs», who were said to be bent on defiling the Corpus Christi in all its religious and social forms. As put by the chronicler William of Breton (d. 1223), each year the Jews immolabant et communicabant, they sacrificed and - literally - took communion with the heart of (that surrogate Eucharist) a Christian boy. This idea, moreover, 
Breton continues, was commonplace in the Capetian palace about 1179, four centuries before Trent. Nor was it something wrung out of a Jew through torture. Indeed, tales of ritual murder are often essentially a collection of topoi, with only the purported victim's name, the place, and date changed. And as Miri Rubin explains in her Gentile Tales: The Narrative Assault on Late Medieval Jews (New Haven, 1999), these tales, which she calls useful tales of exemplification, confer legitimacy - and legitimize Christian response.

If, then, these accusations could develop out of Christian need - and without Jewish input-why should we believe ritual murder actually occurred? Thomas of Monmouth's account of William of Norwich, for one, is a later concoction, out of thin air. Yet Toaff treats Thomas's "facts" as real, just as he never bothers to say that the 1329 murder charge in Savoy was rejected as folly by Christian judges. Toaff would have us believe that the specific charge of mixing blood in the haroset (the fruit and nut mix eaten on Passover to recall the mortar Jewish slaves used in Egypt) was true. He is also distracted by his inexplicable sub-theme that all "deviant" Jewish behavior was of Ashkenazi origin-Jews from German regions-as were the Jews in Trent in 1475. However, the custom of eating haroset on lettuce, as was charged at Savoy, is sefardi and italqi. Ashkenazim accompany haroset with horse-raddish. The late Isadore Twersky whom Toaff cites to show Ashkenazim were haughty, said the same of Spanish rabbis, whereas Italians freely absorbed from all Jewish traditions (Italia Judaica I, Rome, 1983, pp. 390-391). This is not the first time Toaff has sustained loose interpretation. In II Vino e la Carne, he turned four or five records of fights between Jews into statistical evidence of violence over a long period. The examples can be multiplied.

Also perturbing are the constant references to practical (magical) kabbalah, which was more typical of the late seventeenth and eighteenth century, as indeed is the origin of most works of this nature that Toaff cites. Earlier references to Jewish magic, treated as reliable, often come from the writings 
of Bishop Hinderbach of Trent, the chief antagonist in 1475. In citing Hinderbach in this context, Toaff's method reminds us of the original seventeenth century Bollandists (as opposed to their twentieth century heirs), who strove to validate the chronology of their sources, but failed to ask whether what the sources said was true. Yet Pasque di sangue can also be disingenuous. Toaff brings legitimate sources on the use of animal blood for medicinal purposes, which he then melds («sia animale che umano», 103) with supposed confessions about the need for human blood. But these confessions are reported at a distance, and once again by drawing on Bonfelli and Divina, as well as the fifteenth century Franciscan Alfonso de Espina, whose Fortalitium fidei against Jews makes hairs stand on end.

Ultimately, Pasque di Sangue comes across as the product of deliberate imagination rather than reasoned historical thought. To correct the book, as Toaff proposes, would mean to phrase the whole hypothetically and to discard a raft of tendentious (especially secondary) sources, leaving the book with essentially nothing to say. A pity, for Toaff's materials could have led to a master book about beliefs and their reception, for which a starting point could have been chapter 10, which discusses Christian and Jewish attitudes toward blood. As its stands now, Pasque di sangue is full of "sound and fury". It signifies nothing more.

\section{Addenda: Specific issues.}

1. The early assertion that Ashkenazi Jews were especially concerned over forced conversion, so that they were the "first" to insert clauses about this into their documents of protection is perplexing. Such clauses are found in nearly every medieval charter, not to mention, in particular, in the twelfth century papal bull known as Sicut iudaeis non.

2. Toaff never questions whether Jews might have absorbed ideas from Christians, which they then regurgitated under torture, knowing precisely 
what the judges wanted to hear.

3. In chapter 3, he simply says that Jews (45) met to plan death of Christian children and how to use of their blood, but this information comes from the Trent trial records, which we, apparently, are to take literally as accurate. From a report from Crete in 1755 (49), that Jews roast a Passover lamb head up, Toaff deduces that this was an imitation of the crucifixion. Any such conclusion sounds like a Christian perception of a strange rite, just as Rigord, in the early thirteenth century reported that Jews gave their children cakes in wine which they had poured into a pawned communion chalice. No doubt, this was Rigord's fantasy about what the Jews were doing - a counter Eucharist following his description - in the ceremony initiating children into the study of Torah. As for the Ashkenazim, Toaff says (58-top 59) they were isolated, closed in, unable to overcome traumas and their «proprie contraddizioni ideologiche» (whatever that means); theirs was a world of myth and necromancy, magic, etc. Yet the confirmation of this conclusion comes from none other than Hinderbach himself, (59-60) in the bishop's remarks about supposed Jewish magic, offered alongside a report from 1594 by Filippo Neri! that Hinderbach spoke of the Jews chabalà. Toaff explains that this was «practical» kabbalah, which, for him, is synonymous with (black) magic. He even refers to the charge about this in Pius V's 1569 bull of expulsion.

4. On page 64, he writes of Ashkenazi collective memory, but cites the sixteenth century Yosef HaKohen — who was a Sefardi.

5. He keeps building (71) on Bonelli, from 1747, but never asks whether the flood of blood accusations in the South Tyrol and upper Veneto at the end of the fifteenth century really represent a plague of rumors, which passed from town to town - or were locally useful, just as past rumors and charges had provided pretexts for building or supporting shrines.

6. At chapter 5 , n. 7 , he introduces a further suspect source: «Sugli omicidi rituali e i processi di Endingen del 1470 esiste un'ampia bibliografia. 
Rimandiamo in particolare a H. Schreiber, Urkundenbuch der StadtFreiburg im Breisgau, Freiburg, 1829, vol. II, pp. 520-525; K. von Amira (a curadi), Das Endinger Judenspiel, Halle, 1883».

7. In speaking again of so called practical, magical kabbalah (about 102), he cites Eliahu of Loanz, the Baal Shem of Worms, who died, however, in 1636. The developments between 1475 and then were enormous, not to mention citing the much later Moshe Haim Luzzatto or reports from converts like that of the dangerous Paolo Medici, who lived in the later 17th century. By contrast, see the online essay of Moshe Rosman http://www.biu.ac.il/JS/JSIJ/1-2002/Rosman.pdf, which describes the flowering of practical kabbalah in the eighteenth century, especially in Eastern Europe - and Polish Jewish culture, as we now know, was notably different from that of German Jews, the Ashkenazim. To be fair, some texts cited do originate in the sixteenth century, but they are freely mixed with later ones, to give the impression - especially to the uninitiated - that they form an unbroken skein.

8. Pages 100-09 argue that rabbis permitted the use of blood for medication. This, however, was animal blood. References to human blood come only from Bonelli and Divina, and the Trent processi. Once again, the tortured accused were likely confusing popular usages with what inquisitors wanted to hear. The link to saying human blood was used was the action of sucking blood from the head of the penis during circumcision, mixed with wine, an unusual ceremony, which, in the event, provides no intrinsic link to using the blood of Christian children.. But that which makes the connection possible is the (above cited) phrase sia animale che umano (103), Toaff's own, which is also his "strongest evidence" for Jews using blood - Christian blood - in rituals. Superfluo dictu, this is evidence by sheer allusion, about which, Toaff seems aware. The full text (here, below), contains an implicit denial: the phrase «a prima vista». But, as the narrative continues, any doubt is left behind: 
In tutti i casi esaminati in precedenza, e in gran parte presenti nelle raccolte di segullot, rimedi e medicamenti segreti, redatti e diffusi dai maestri della Cabbalah pratica, abbiamo a che fare con un uso per così dire esterno del sangue, sia umano sia animale, essiccato o diluito, con funzioni terapeutiche ed esorcistiche. Ma l'accusa rivolta agli ebrei di cibarsi di sangue, servendosene a scopi rituali o curativi, in trasfusioni per via orale, appare a prima vista destituita di qualsiasi fondamento, essendo in palese contrasto con le norme della Bibbia e della ritualistica successiva, che non ammettono deroga alcuna al divieto.

Regardless, the real manipulation is in the first emphasized phrase, for, as said above, the Hebrew sources never speak of human blood.

9. Chapter 7 rehearses earlier accusations, with a hint that the events, as retold by Christians, were real, and, thus, when on page 120, Toaff refers to confessions (he means those in chapter 6), we are supposed to give these confessions credence. We are also seduced into thinking that there is something true about all the earlier accusations, dating from the twelfth century, an effect achieved by just rehearsing these accusations with no observation about their veracity (he never cites the revealing hagiographic texts in the Bollandist Acta Sanctorum). Once again, this is affirmation by allusion.

10. Chap. 8, 128, states: «Che l'Europa cristiana del Medioevo temesse gli ebrei è un fatto assodato» is too strong. There were fears of Jews, but to make so bald a statement is surprising from somebody who has constantly argued Jewish-Christian rapprochement, if in Italy, and this would have to include Ashkenazim there, too. The assertion that Jews controlled the early medieval slave trade is also too sharp. Verlinden's argument to this effect has been questioned time and again. Jews may have participated in this trade, but they did not dominate it. Agobard, the major witness for the argument, had paroxysms about contact with Jews. He can hardly be taken at face value about anything. As for cookies with Haman's image on them, 
perhaps, but this does not justify writing «Aman-Cristo». Just because Jews may have called both Haman and Christ "the hanged one" (talui), and Jewish mock hangings of Haman had long been suspected of being vicariously those of Jesus, does not mean that Jews consciously were drawing images of Christ on their Purim sweets. Besides, Toaff's description of these cakes is taken from a nineteenth century manual. To cite the sixteenth century Marquardus de Susannis is also strange. Though a careful jurist, de Susannis believed all the accusations and reported them. But whether, as we are deliberately led to assume, that means anything substantial, something more than that even the cleverest among Christians might believe the worst, I strongly doubt.

11. Chapter 9. In the discussion of the Crusade Chronicles, the cart comes before the horse. The chronicles came decades afterward. We do not know the real dimensions of either forced conversion or martyrdom. But the real issue is that Toaff introduces these chronicles in order to allow him to sustain, and then expand on, Yuval's highly arguable thesis that Jews spilled their own blood in 1096 in order to invoke divine intervention that would bring the messiah, which is then translated into the idea that Jews decided to wage the vendetta themselves. Yet why should the Jews take divine vengeance into their own hands? More, one needs a verbal link, not just an imaginative one, and the reliance on texts in the Zohar to make this link is odd, since the Zohar is cited and taken for its literal meaning. However, no passage in the Zohar may ever be taken without adducing a river of symbols and symbolology. Purim verbal violence, in addition, should not be ipso facto converted into acting out, claims about which in the pre-modern period or earlier have never been backed up by solid proof, the essays of Horowitz included, who has the bad habit of taking Christian hagiographical texts literally.

12. Chapter 10 is interesting, because it shows images of flowing blood and where they may have been in common among Jews and Christians. Had the book concentrated on this theme, it might have been excellent. Instead, the 
emphasis is on the - unsubstantiated - conversion of these images into supposed fact.

13. Chapter 11. Of course, Jews had a negative image of Christianity. The Nizzahon Yashan, as I read it, implies the Eucharist is a cannibalistic sacrifice to the biblical Moloh, and the Eucharist was described as droppings. And certainly Purim would bring strong expressions. Anyone who expects otherwise is naïve, including the cry that Christ is boiling in a hell of ordure in the mouth of somebody about to kill himself rather than be converted by force. However, to go from these negative motifs to saying: «ll Seder si trasformava cosi in una clamorosa manifestatzione antichristiana», is a blatant distortion. The Passover Seder is about so much much more; negative remarks about Christianity, always though implication, were asides. The movement from such remarks to actual vendetta is through manipulating the words of the convert G. Morosini and the record of the Trent processo, which is about as justified as taking every cry to "ti amazzo", and turning it into a (potential) homicide; the reasoning is that outlandish.

14. Chapter 12 begins by simply assuming Jews put blood in the matzot used for the Seder, a claim that rests exclusively on continuing the symbolism of chapter 11, and, once again, Toaff relies on Divina and Bonelli. He introduces the term shiksa, brings lots of text, but then admits the term it is not in the Trent trial record, and he is over-suggestive about the meaning of goi, the term that was consistently used for Christians, even by Roman Jewish notaries drawing contracts. There is no praise here, but the notaries used goi even when a Jew chose a Christian to act for him or her as arbiter, a position of trust, not one given to somebody one was about to slaughter to drain his or her blood. The Toledot Yeshu is also overplayed. It is an old text, the motifs, hardly flattering, were possibly in place over a millennium before Trent. Nor was the book of a necessarily Ashkenazi origin, as an unsuspecting reader might think; Professor Pines thought the origin was actually Monophysite. This brings us back to the obsessive concern with Ashkenazi behavior, which has no real justification, certainly not in the 
material brought, including the attempt to show Ashkenazim never blended with others. In Rome, at least, by the earlier sixteenth century, they were increasingly intermarrying with others. Rome is special, but the records there, at least, are precise.

15. Chapters 13 and 14 draw on the most negative images possible of Christianity, which are then blown up, with the narrative proceeding to the processo, to suggest a passage from motif to murder, a passage achieved simply by the narrative flow in the book, not by any proved or even hypothesized nexus. On one page there is motif, the next a description of murder; ipso facto, motif generated homicide. There is no demonstration, no questioning, no wondering how admissions of murder got into the trial which, as I have said above - is likely because the Jews, under enormous stress, were drawing on whatever they knew and had heard, including from Christians, to have the torture stopped. For this kind of behavior, there are plenty of precedents that have been well studied.

16. Chapter 15 seems to be preponderantly a transcription of Bonelli, judging from the citations in the notes, fleshed out with material from Divina. It is not even, therefore, a rereading and interpretation of the trial record itself, rather an uncritical recounting of what ultimately is secondary literature, even if the material in that literature is in Latin. In other words, it is consistent with the method adopted throughout the book, which is to say, no method at all beyond juxtaposition and totally self-assured narrative assertion.

\section{Note}

* Kenneth Stow is Emeritus Professor at the Università of Haifa, Israel. He has published many works concerning Jewish history and the history of Roman Inquisizione during the modern age; among the others: Catholic Thought and Papal Jewry Policy (1555-1593) (New York 1977); Alienated Minority: the Jews of Latin medieval Europe (Cambridge MA, 1992); Theater of Acculturation: the Roman Ghetto in the 16th century 
(Seattle 2001); Jewish Dogs: An Image and its Interpreters (Stanford CA., 2006). 